\title{
Diamonds from the Guaniamo area, Venezuela
}

Kaminsky, F.V. ${ }^{1}$, Zakharchenko, O.D. ${ }^{2}$, Channer, D. M. DeR. ${ }^{3}$, Blinova, G.K ${ }^{2}$, and Maltsev, K.A ${ }^{4}$

1. KM Diamond Exploration, 815 Evelyn Drive, West Vancouver, B.C. V7T 1J1, Canada, Tel. \& Fax (1-604) 9258755, E-mail: kaminsky@fox.nstn.ca

2. Institute of Diamonds, Russian Academy of Natural Sciences, 155-5/10 Litovskii Blvd., Moscow 117593, Russia

3. Guaniamo Mining Company, Centro Gerencial Mohedano, Cruce Av. Mohedano, Urb. La Castellana, Caracas, Venezuela

4. Vernadsky Institute of Geochemistry and Analytical Chemistry, Russian Academy of Sciences, Moscow, Russia

Diamondiferous placer deposits were discovered in the Guaniamo area in 1968, and since then approximately 20-25 million carats have been produced from this area. Stones up to 40 and 60 carats in weight have been reported here. Recently diamondiferous kimberlite sills were discovered in the Quebrada Grande, Guaniamo River right tributary valley which are the primary sources of the diamonds. We have studied over 4,000 diamonds from both, kimberlites and placer deposits.

Morphology. Diamonds from the Guaniamo area include dodecahedroids, octahedra, octahedron + dodecahedroid (O-D) combination-type crystals and their twins and aggregates. In all sills and placer deposits, dodecahedroids are predominant, accounting for about $45-50 \%$ of the respective samples. Combination-type O-D crystals are also present in rather high proportions, sometimes up to $23 \%$ of the samples. All dodecahedral diamond crystals are rounded dodecahedroids. Eight groups of them were distinguished based on the nature of the dominant crystal surface. Dodecahedroids with concentric striation are predominant. They compose $60-70 \%$ of all dodecahedrical diamonds. Octahedral diamonds are subdivided into the following three groups: (1) Octahedra with stepwise lamellar development of trigonal faces, (2) Octahedra with clearly concentric development of crystal faces and (3) Octahedra with bitrigonal faces. Diamonds of the last type are commonly predominant. Single cubic-habit crystals were found. They are represented by tetrahexaedroids and combination-type crystals. There are many varieties of twinned and aggregated diamonds. Their proportion in the larger diamonds increases. Macles, or octahedral spinel-type twins are most common. Only a small number of diamonds from the Quebrada Grande placer show post-magmatic mechanical erosion features and, may therefore have been transported over some distance.

By color, colorless diamonds are predominant: they comprise $40-50 \%$ of all diamonds, but in some placers form up to $70 \%$ of stones. Smoky-brown, grey and green stones account for $10-20 \%$ each of all stones. $60-80 \%$ of diamonds have pigmentation spots. These are typically isolated spots that do not affect the overall coloration of the crystal. Rarely, these spots occur in clusters. In the overwhelming majority of cases, the spots are bright green. However, several diamonds showing brown pigmentation spots were found in the Quebrada Grande placer collection.

All the sills studied have a marked predominance of diamonds showing blue photoluminescence (PL) and a rather high proportion of crystals exhibiting no visible luminescence. In general, PL characteristics of diamonds from the Guaniamo sills are identical to those of diamonds from the Guaniamo placer deposits. $55.8 \%$ and $57.6 \%$, respectively, of the diamonds in these two groups, 
have blue luminescence. The diamonds from the sills and placers also show similar abundances of stones with yellow-green and pale pink luminescence, of diamonds with uncertain PL color and, of diamonds with no visible luminescence. Diamonds from these two sources which exhibit inhomogeneous luminescence show only very small differences. Hence, diamonds from the sills and the placers are essentially identical in their luminescence characteristics, and the sills are therefore interpreted as representing the major source of Guaniamo placer diamonds.

Diamond IR spectra from the sills and placers are rather similar. They all show bands representing $\mathrm{IaA}, \mathrm{IaB}$ and $\mathrm{P}$ (platelets) nitrogen impurities and do not show resolvable concentration of single nitrogen atom impurities of type Ib. Type II diamonds were not found in the samples studied. All Guaniamo diamonds studied belong to the transitional IaAB type. More than half the grains show significant amounts of hydrogen structural impurities, while the remainder appear to contain moderate amounts. The majority of diamonds show a predominance of IaB-type nitrogen impurities compared to IaA impurities, though in a few crystals, IaA nitrogen impurities are more abundant than $\mathrm{IaB}$ impurities. As much as $20 \%$ of all diamonds studied contain relatively low $\left(5 \times 10^{19}\right.$ atoms $/ \mathrm{cm}^{3}$ ) concentrations of all three types (IaA, IaB and B) of nitrogen impurities. Concentrations of IaA nitrogen impurities and hydrogen impurities are not very high. Their range in concentration are $0.6-17.3 \times 10^{19}$ atoms $/ \mathrm{cm}^{3}$ and $0.3-3.5 \mathrm{~cm}^{-1}$, respectively. IaB nitrogen impurities are typically more abundant than IaA impurities, with concentrations ranging from 1 to $4 \times 10^{19}$ atoms $/ \mathrm{cm}^{3}$. Concentrations of B nitrogen impurities range from 0.4 to $10.8 \times 10^{19}$ atoms $/ \mathrm{cm}^{3}$, commonly approaching IaA impurity concentrations. The predominance of $\mathrm{IaB}$ and $\mathrm{P}$ nitrogen impurities over IaA impurities in the diamonds studied suggests that Guaniamo area diamonds are characterized by higher temperatures of formation than diamonds from Siberian pipes.

The total range of variation in carbon isotopic compositions of Guaniamo diamonds analyzed is from $\delta^{13} \mathrm{C}=-3.2 \%$ to $-28.7 \%$. The majority of diamonds are isotopically light, i.e., show $\delta^{13} \mathrm{C}$ $<-10 \%$ (from -10.1 to $-28.7 \%$ or for $95 \%$ of diamonds).

Guaniamo district diamonds contain both eclogitic- and ultramafic-suite mineral inclusions. Diamonds containing eclogitic-suite inclusions are predominant. For example, only $10 \%$ of garnets belong to the ultramafic association. The finer the diamond size, the greater is the proportion of eclogite-type inclusions.

Eclogitic (E-type) garnet of the pyrope-almandine series have rather high $\mathrm{CaO}$ content in most of the garnets (up to $10-13 \%$ ) and do not have high $\mathrm{Na}_{2} \mathrm{O}$ content $(0-0.26 \%$ ). Omphacite clinopyroxene, like orange garnet, occurs relatively commonly as inclusions in the diamonds studied. In some cases, composite pyroxene and garnet inclusions are observed. $\mathrm{Na}_{2} \mathrm{O}$ content varies from $3.63 \%$ to 7.46 wt. \%, which correspond to 25 to 51 mol. \% jadeite component. $\mathrm{Al}_{2} \mathrm{O}_{3}$ content varies from 7.21 to 13.53 wt. $\%$, and positively correlated with $\mathrm{Na}_{2} \mathrm{O}$. In addition, pyroxenes included in diamonds from the Guaniamo area exhibit rather high concentrations of $\mathrm{Na}_{2} \mathrm{O}$. Diamonds that contain orange garnet and omphacite inclusions also commonly enclose colorless mineral inclusions which considering the E-type paragenesis of these diamonds, are probably formed by coesite. The rutile inclusions have compositions which are typical of E-type rutile inclusions in diamonds. Ilmenite inclusions were found in two diamonds. Ilmenite in diamonds from other diamondiferous areas worldwide are commonly very rich in both $\mathrm{MgO}$ and $\mathrm{Cr}_{2} \mathrm{O}_{3}$. A notable feature of the ilmenite inclusions from the Guaniamo area studied here is their rather low $\mathrm{MgO}$ content, from 0.91 to 1.04 wt. \%. Mg-poor ilmenite inclusions were previously 
found in only two other diamonds, from Brazil by Meyer and Svisero [1975]. The ilmenites studied are also notably characterized by high $\mathrm{MnO}$ content (about 1\%). Sulphides were also found included in some Guaniamo area diamonds. Based on their compositions, in particular their low $\mathrm{Ni}$ content, they are interpreted to be eclogitic.

Ultramafic (UM-type) inclusions include Cr-garnet, chrome spinel and olivine. Olivine inclusions in diamonds from the Guaniamo area have $93-94.5 \%$ forsterite contents and contain insignificant amounts of $\mathrm{Cr}_{2} \mathrm{O}_{3}$ (0.04-0.08 wt. \%), $\mathrm{CaO}$ (0.01 wt. \%) and $\mathrm{NiO}(0.33-0.39$ wt. \%). The chromite inclusions have $\mathrm{Cr}_{2} \mathrm{O}_{3}$ and $\mathrm{Al}_{2} \mathrm{O}_{3}$ contents ranging from 63.6 to 66 wt. \% and 6.76 to 7.25 wt. \%, respectively, which is typical for chromite inclusions in diamonds from the majority of diamond deposits worldwide. All of the pyrope inclusions are high-Cr knorringite-bearing garnets (6.9 to 13.8 wt. $\% \mathrm{Cr}_{2} \mathrm{O}_{3}$ ) with low iron contents (13.5-15.0 wt. \% FeO). One of the $\mathrm{Cr}$-pyropes studied appears to be $\mathrm{Ca}$-poor, and the other three have rather high $\mathrm{Ca}$-contents. Two of them fall within the lherzolite field, which is somewhat atypical for pyrope inclusions in diamonds. The other two garnets fall within the diamond-association field, with one having rather low $\mathrm{Ca}$ for this field. One diamond contains a titano-magnetite inclusion. In another diamond, a single notable occurrence of included magnesio-wustite was observed. It has the following composition: 0.15 wt. $\% \mathrm{Cr}_{2} \mathrm{O}_{3}$; 19.42 wt. \% FeO; 80.12 wt. \% MgO.

Four diamonds have composite inclusions of coexisting garnet and clinopyroxene. Equilibrium temperatures and pressures for these mineral pairs lies within the range $1186-1218{ }^{\circ} \mathrm{C}$ temperature and 41.4-61.5 kb pressure. These results are consistent with results of the IR studies that Guaniamo diamonds have higher pressure-temperature conditions of formation than diamonds from most of the other diamondiferous areas worldwide.

Diamonds from different sills are distinct in most of their properties. This distinctiveness of diamonds from each of the sills can be used as a "diamond fingerprinting" tool in prospecting.

\section{References}

Baptista, G.J., and Svisero, D.P., 1978, Geologia de los depositos diamantiferos de la parte norooccidental de la Guayana Venezolana: Republica de Venezuela, Ministerio de Energia y Minas, Direccion General Sectorial de Minas y Geologia, XIII, No. 24 (Agosto, 1978), p. 3-46.

Meyer, H.O.A., and Svisero, D.P., 1975, Mineral Inclusions in Brazilian Diamonds: Physics and Chemistry of the Earth, 9, p. 785-795.

Nixon, P.H., 1988, Diamond source rocks from Venezuela: Indiaqua, 51, p. 23-29.

Nixon, P.H., Griffin, W.L., Davies, G.R., and Condliffe E., 1995, Cr garnet indicators in Venezuela kimberlites and their bearing on the evolution of the Guayana craton: Kimberlites and related rocks, 1, Brasilia, p. 378-380.

Svisero, D.P., and Baptista, G.J., 1973, Inclusions en los diamantes de la Quebrada Grande, Distrito Cadeno, Estado Bolivar, Venezuela: II Congr. Lat. Amer. Geol., Caracas, 1973, Resumenes, p. 158160. 